\title{
'The Best Field for Tourist Sale of Books': Marius Barbeau, the Macmillan Company, and Folklore Publishing in the I930s
}

\author{
Andrew Nurse ${ }^{\dagger}$
}

When Marius Barbeau was hired as an assistant ethnologist by the newly established anthropology division of the Geological Survey of Canada in I9I I, publishing was part of his job description. 'A great deal of the work of a Government bureau,' acting Survey director R.W. Brock explained to Barbeau, 'is the collecting, preserving and presentation to the public of original data. . .' ${ }^{\mathrm{I}}$ Barbeau took this mandate seriously. At the time of his death in 1969 his bibliography stretched to over I,ooo items, including ethnographic and folklore studies, a novel, catalogues raisonnés, bibliographical works, art histories, introductions to exhibition catalogues, prefaces to concert programs, divisional reports for federal sessional papers, and book reviews. ${ }^{2}$ It was common for Barbeau to be working on several projects simultaneously. As he explained to one of his publishers, Hugh Eayrs of Macmillan of Canada, in I935: 'I actually now have six books . . . accepted by publishers now; and eight more ready waiting for a decision. . . .'3

Of all the various types of writing in which Barbeau engaged, his folklore material proved the most difficult to publish. The reason for this was simple: before the Second World War the market for Canadian folklore writing consisted primarily of a limited body of disciplinary specialists. When Barbeau first began to publish folklore in the mid-I9IOs, this limited market did not present itself as a significant obstacle because his publications were directed to this audience and subsidized through grants or other means. ${ }^{4}$ When Barbeau attempted to broaden his audience beyond its disciplinary base in the I930s, however, this limited market emerged as a

+ Andrew Nurse lives in Halifax, Nova Scotia. His recently completed doctoral dissertation is a study of Marius Barbeau and the development of modern anthropology in Canada. 
major impediment. His publisher, Eayrs, was unwilling to print his material without some means of guaranteeing that Macmillan would not suffer a substantial loss. Barbeau's major folklore work, the Romancero du Canada, was delayed for half a decade while he and Eayrs attempted to arrange some means of subsidizing it.

The process of arranging support for folklore publications involved at times a complex series of negotiations which became, for Barbeau, part of the publishing process. His other major folklore works from the I930s, The Kingdom of Saguenay and Quebec: Where Ancient France Lingers, were subject to an equally significant, if less complicated, process of negotiation before their publication. Barbeau was an active part of this process. His own interests and willingness or unwillingness to accept the terms of publication suggested by different publishing houses affected both the date of publication and the form of each of these three books. This paper explores the dynamics of folklore publishing in the I93os through an examination of the negotiations that surrounded the publication of the Romancero, The Kingdom of Saguenay, and Quebec. It examines Barbeau's interest in, and rationale for, folklore research and publication, the obstacles which delayed the publication of the Romancero, Barbeau's involvement in the negotiations surrounding the publication of his folklore books, and the way in which the publishing process reshaped the public presentation of folkore.

Marius Barbeau is widely considered to be the founder of folklore studies in Canada. In the interwar years he became a prominent public figure. As a leading Canadian anthropologist, award-winning author, and the publicly recognized leading authority on FrenchCanadian folklore, his scholarly accomplishments earned him two honorary doctorates, an honorary fellowship to Oriel College, Oxford (his alma mater), three prix David, and a range of other awards. Although he spent most of his career with the anthropology division and the National Museum in Ottawa, he also taught at the Universities of Ottawa and Montreal and at Laval University. In a sense, Barbeau's scholarly and cultural accomplishments are surprising. When he was born no one could have predicted he would become an anthropologist and folklorist, let alone a recognized and honoured authority on these subjects. In fact, his parents attempted to chart a very different future for him.

Barbeau was born into an established and locally prominent family in 1883 in Ste-Marie-de-Beauce. His extended family included a former mayor of Ste-Marie, church wardens, a real estate promoter 
and textile mill owner, and some of the richest men in the Beauce, although his own immediate family never attained this level of prosperity. His father was a farmer who was also involved in the lumber trade and who appears to have had little interest in cultural and intellectual matters for their own sake. However, his mother, a former Grey Nun novice who had quit her order to marry Barbeau's father, was an educated and cultured woman who taught music, played organ for the local church, and encouraged her son to become a priest. His mother educated Barbeau at home until the age of eleven when he was enrolled in a local commercial college. After three years he transferred to classical college and began to prepare for a university education. A loss of faith led Barbeau to reject his mother's goal for him, and he entered Laval University in I90I to study law. At Laval Barbeau proved an able student. He won a Rhodes scholarship and in 1907 departed for Oxford to continue his legal education. At Oxford he rapidly lost interest in law and shifted the focus of his studies to anthropology. Under the direction of the noted British anthropologist R.R. Marett, he completed his diploma in anthropology, writing a senior thesis on the 'totemic system' of the Pacific Northwest Coast First Nations. In I9I I he was appointed to the anthropology division of the Geological Survey of Canada where he continued his study of Canada's aboriginal peoples. ${ }^{5}$

Barbeau began to collect and study French-Canadian folklore at the suggestion of Franz Boas, the noted American anthropologist, whom he had met at the American Anthropology Association annual meeting in I9I3. At the time Barbeau had just completed an ethnographic survey of Huron-Wyandot culture for the anthropology division and was in the process of writing up the results of this survey for publication. The anthropology division was then under the direction of Edward Sapir, a former student of Boas. It had been established by the federal government in I9ro in response to persistent demands from the Canadian scientific community and British anthropologists who were concerned about the 'disappearance' of aboriginal cultures in Canada. Sapir aimed to use the resources of the division to complete a systematic ethnographic survey of aboriginal peoples in Canada,${ }^{6}$ and as part of this program he had sent Barbeau to the Huron community of Lorette in I9I I to begin fieldwork on this culture. By Barbeau's own account there was nothing unusual about his Lorette field research; in fact, he felt it was a considerable success. He managed to collect a sizeable number of ethnographic 'artifacts' and to secure a considerable body of 
information relating to Huron religion and social organization. However, in the course of his field work, Barbeau noted what he felt was one interesting cultural idiosyncrasy: on at least one occasion when he asked a Lorette Huron to recite traditional songs, so he could record them, the person sang songs which Barbeau recognized as being of French-Canadian origin. ${ }^{7}$ At the time Barbeau considered the presence of French-Canadian songs among the Lorette Huron to be a 'curiosity' and seems not to have troubled himself with the matter, ${ }^{8}$ but when he mentioned this 'curiosity' to Boas, the elder man was immediately fascinated by it. Boas felt that a survey of French-Canadian folklore would complement work he and his students were doing in the United States on cultural development in that it would allow anthropologists to gauge the impact of French culture on aboriginal cultures in North America. He urged Barbeau to begin a survey of French-Canadian folklore, promised to secure the support of Sapir for the project, and agreed to publish the results of Barbeau's research in the Journal of American Folk-Lore. ${ }^{9}$

On the urging of Boas, Barbeau returned to Lorette in I9I4 to record the French-Canadian material that he had earlier disregarded. His results were, he felt, impressive: ' . . I I have collected over twenty-five interesting French-Canadian tales, most of which are reasonably long, and well preserved,' he told Sapir. '[T]hey will constitute a splendid set of first-hand French-Canadian stories. ${ }^{\prime \prime}$ Over the next several years Barbeau broadened his folklore research across rural Quebec. He worked at the Éboulements, the Gaspé Peninsula, Île-aux-Coûdres, Ile d'Orléans, the Richelieu River region, Assomption County, the Beauce and a series of other locales. The results considerably surpassed his expectations. During one fieldwork season on the north shore of the St. Lawrence and the Gaspé Peninsula in 1918 , for example, Barbeau collected I, 300 songs. ${ }^{I I}$ His collection eventually grew to include over 13,000 song texts and 7,000 recorded melodies. ${ }^{\text {I2 }}$

Barbeau began to put this material into print in I9I6. He edited a series of French-Canadian numbers for the Journal of American Folk-Lore which began appearing that year. The aim of these publications, as Boas told Barbeau, was scientific. Boas wanted Barbeau's material published through the Journal to facilitate anthropological and folklore research ${ }^{13}$ and Barbeau subscribed to this aim as well. 'Tous les articles ou essais de ces séries sont scrupuleusement et sèchement scientifique,' he told one correspondent, 'on n'y fait nul sacrifice au goût populaire ou à l'art pour l'art..' ${ }^{\prime 4}$ At the same time, Barbeau began to feel that the extensive nature and quality of the 
material he was collecting warranted publication in a more popular format, and he started to think about publishing a collection of folk songs similar to the Chansons populaires du Canada published by the musician Ernest Gagnon in I865. ${ }^{15}$ French-Canadian folk culture material had been published in popular formats sporadically throughout the nineteenth and early twentieth centuries. Some late nineteenth century English language texts also referred to what their authors took as the more colourful aspects of traditional French-Canadian life and at about the same time tourist industries began to make tentative efforts to exploit the potential appeal of folk culture for the foreign traveller. ${ }^{16}$ But, by the I9 Ios Gagnon's collection remained the only generally accessible source on this subject $^{17}$ and what struck Barbeau was the marked paucity of published folklore texts compared to the wealth of material he had discovered in the Quebec countryside. 'Were even only half of [my] material to be published,' he explained to Sapir as early as I9I 8, 'it will surely astound both French and Canadians as to the resources of oral traditions. ${ }^{\text {I8 }}$

As he conducted his folklore field research Barbeau also began to think about traditional popular culture in a different way. He began to see traditional culture as representative of the true cultural essence of French Canada - a culture which was purer than modern culture because it was directly connected with popular life. Music was of particular importance in traditional culture, in Barbeau's view, because it became integrated into every aspect of popular life. 'Folk songs were once part of the everyday life of French America,' he explained on one occasion. 'They seem as familiar as barley bread to the pioneer settlers of the St. Lawrence Valley. ... [T]hreshing and winnowing in the barn moved on to the rhythm of work tunes, as did spinning, weaving and beating the wash by the fire.' ${ }^{19}$ The problem with this culture, in his view, was that it was disappearing. Of all the areas of French settlement in North America, he noted, only in Quebec did this folk culture retain its vitality and even here it seemed threatened. 'Que reste-t-il,' he asked in one text, 'dans les campagnes, de nos chanteurs et de nos conteurs d'autrefois; dans les écoles, des jeux et des rondes de la jeunesse; et au foyer, des dires et des rimettes de l'enfance? Le répertoire des traditions populaires tombe dans l'oubli. ${ }^{20}$ It was necessary, he believed, to preserve this culture while there was still time. Barbeau, however, became interested not simply in preserving folklore and confining it to the museum or the academic monograph. He was interested, as well, in using the collections he created to re-popularize folk culture in 
the modern age, to restore, as it were, the pure culture of the traditional past. Barbeau believed that, among other things, this required popularly oriented publications.

This objective was in part realized in 1925 when Yale University Press published Folk Songs of French Canada. This collection of folk songs appeared under the names of both Sapir and Barbeau, but its forty-one selections were drawn largely from Barbeau's fieldwork and Sapir appears to have been only peripherally involved in the transcription and notation of the material. His main contributions to the book appear to have been translating the songs into English and securing the publisher and a grant to underwrite publication costs. ${ }^{21}$ Folk Songs of French Canada was intended by its authors to refute the idea that Gagnon's collection represented a definitive and exhaustive survey of folk music in French Canada and to broaden knowledge of traditional French-Canadian culture beyond the parameters of specialists in anthropology and folklore. The book, Barbeau and Sapir explained in its 'preface,' was designed to appeal to the general public and also to maintain scholarly standards in the presentation of the material. 'It is our intention,' they wrote, 'to avoid the two extremes of technicality and of sentimentalism, and we have tried to reach both the folklore student and the general reader who wishes to get a taste of this fascinating folk literature. ${ }^{22}$

The critical response to Folk Songs of French Canada was generally positive, ${ }^{23}$ but Barbeau was of two minds about the collection. On the one hand, he was happy to have the collection in print. Other folklorists, he told Sapir, had been unable to interest publishers in similar material and a proposed translation of Gagnon's collection had met with no response. 'So,' he explained, 'we may be thankful for our luck.' On the other hand, Barbeau questioned the overall quality of the material he had published. The selections, he complained, had been 'largely accidental' (i.e., devised without systematic attention to their quality) and they were 'therefore not always the best' of the material he had collected. ${ }^{24}$

Following the publication of Folk Songs of French Canada, Barbeau arranged the publication of a number of other songs through various venues, ${ }^{25}$ but his intention was to produce a large, systematic collection containing the best folk songs he had collected. By I93 I Barbeau believed his research had reached the stage where it was possible to publish his material in this fashion, and approached Hugh Eayrs, president of Macmillan of Canada, with a proposed book, to be called Romancero du Canada, which would accom- 
plish this aim. ${ }^{26}$ The Romancero was, in Barbeau's view, his most significant folklore project. It would be published in French; it was designed to become a multi-volume series; and would contain an extensive musicological apparatus. Barbeau believed that the Romancero held immense potential. The book itself would be a revelation in that it would illustrate the extent and aesthetic quality of French-Canadian folk music. It could, he felt, not only replace Gagnon's Chansons populaires as the standard collection of FrenchCanadian folk songs, but could also establish the standard for a national musical repertoire by generating revived interest in folk songs. 'Notre Romancero,' Barbeau explained to one correspondent, '... est d'une valeur unique, par la qualité de ses matériaux, par la signification, et par la beauté de ses mélodies. La méthode que je suis dans sa préparation est d'ailleurs soigneuse; ce qui ne veut pas dire qu'elle est définitive. ${ }^{27}$

Barbeau most likely met Eayrs in the early I 920 os when Macmillan published a tourist promotion book he had written for the Canadian Pacific Railways (CPR), Indian Days in the Canadian Rockies, on the Amerindian cultures of the Rocky Mountains. Throughout the I 920 s and early I930s, Barbeau continued to work with Eayrs on a number of other projects, including his prix David winning The Downfall of Temlaham, an account of modern Northwest Coast history based on Tsimshian legends, and a catalogue raisonné of the art of Cornelius Krieghoff, the nineteenth-century painter. Generally, Eayrs seems to have been impressed with Barbeau's historical and art-historical writing. He, along with Macmillan readers, found Barbeau's innovative use of ethnographic evidence intriguing and also felt that his, Barbeau's, attempt to present Canadian history from an aboriginal point of view was culturally significant. ${ }^{28}$ Barbeau's own nationalist commitment to the development of a Canadian literature and art must also have appealed to Eayrs. As David Young has pointed out, Eayrs was personally committed to the same cultural ideas; under his direction Macmillan of Canada undertook publication of a number of Canadian novels which had a clearly limited market appeal. ${ }^{29}$ However, Eayrs balked at the Romancero. The cost of printing, he explained to Barbeau, was so high owing to the engraving necessary for the musical notation accompanying the song texts that Macmillan would require a guaranteed sale of $\mathrm{I}, \mathrm{OOO}$ copies before it could undertake publication. Unlike Barbeau, Eayrs doubted that the Romancero would have any market appeal outside Quebec. ${ }^{30}$

In 1932 Eayrs and Barbeau approached the Quebec provincial 
government for support. They initially won the tacit approval of Premier Taschereau, but then saw Quebec support evaporate when L.A. David, the powerful provincial secretary, proved unwilling to make a financial commitment to the project. ${ }^{3 \mathrm{I}}$ With the collapse of support in Quebec, the Romancero was shelved while Barbeau investigated other ways of publishing the collection, including joint publication with a French-Canadian company, support from an American publisher, having the collection adopted as an achievement prize by the Quebec school system, the potential for sales at tourist sites, and grants-in-aid from different foundations. It proved more difficult to publish the Romancero than Barbeau could have imagined. American companies were uninterested, ${ }^{32}$ John Murray Gibbon, chief publicity agent for the CPR, informed Barbeau that the expected sale at the Chateau Fontenac would be at most two dozen per year, ${ }^{33}$ and grants-in-aid proved similarly unavailable. ${ }^{34}$ Barbeau found a number of Quebec publishing houses who were interested in joint publication, but was unable to work out an agreement with which he and Macmillan were happy. Éditions du Totem wanted Barbeau to forego his royalty in order to lower production costs, a step Barbeau was unprepared to take because of the mounting personal costs he had incurred in his efforts to work out a publishing agreement. He had made, Barbeau told Albert Pelletier of Éditions du Totem, two trips each to Toronto and Quebec at his own expense and for which his royalties would just reimburse him. ${ }^{35}$

There were other problems with Quebec publishing houses as well. In addition to wanting Barbeau to forego his royalty, Éditions du Totem wanted an even larger guaranteed sale than Macmillan, while another company wanted to exclude Macmillan from the Quebec market entirely, including English language bookstores in Montreal. ${ }^{36}$ Because Eayrs considered Quebec the only major market for the Romancero, he was unwilling to accept this division of territory. 'I think our end of it is a much greater risk than his,' he explained to Barbeau; '[marketing] the book in English-speaking territory would obviously be a more difficult task. ${ }^{\prime 37}$

In Barbeau's view, however, the primary problems with Quebec publishing houses were their quality and stability. They lacked, he believed, either the necessary expertise or resources to produce the type of book he wanted to serve as a model for an on-going series. For this reason Barbeau rejected offers from French-Canadian houses to print and publish the book in Quebec. '[B]oth Granger and Beauchemin,' he explained to Eayrs, 'are slovenly in all the work 
they do. We might not care for a Romancero printed by them. ${ }^{138}$ For the Romancero series to be a success, Barbeau believed it was essential that the first volume be established on a stable basis and be presented in a form readers found attractive. This book, he told Albert Pelletier,' sera peut-être la plus importante de toutes. Elle pourrait se continuer en une longue série de beaux volumes. . . Si nous pouvons établir l'entreprise sur des base stables et satisfaisantes, nous pourrons en être heureux de part et d'autre.' 39 Macmillan had two further advantages over French-Canadian houses: an international marketing system, in which Barbeau was clearly interested, and the prestige of a large, established publishing house. 'I am still firm in my decision not to proceed with the publication of the Romancero,' he told Eayrs after one French-Canadian house offered to publish the work on its own in Quebec, 'unless it is, at least in part, published with the imprint of the Macmillan Company. For my aim is to reach an international circulation and to have an old established house sponsor the publication. ${ }^{\prime 40}$

The various problems Barbeau encountered delayed publication of the Romancero throughout the early and mid i93os. In the meantime, however, Eayrs had given Barbeau another idea as to how to publish folklore. In a conversation in early I932, Eayrs had mentioned that Macmillan had recently published a book on the Great Lakes in which the Canadian Steamship Lines (CSL) had taken an interest as part of a program to encourage tourist travel on its Great Lakes lines. During the conversation it occurred to both Eayrs and Barbeau that the CSL might be interested in a similar type of book, which Barbeau would write, on the lower St. Lawrence where the company also ran cruises. ${ }^{4 \mathrm{I}}$ The book would be called In the Heart of the Laurentians and would be specifically designed for the tourist market. 'Les touristes de la Malbaie et de Tadoussac ainsi que du Manoir Richelieu seraient des clients pour ce volume ...' Barbeau later told one correspondent..$^{42}$ Eayrs agreed to broach the idea to T.R. Enderby, general manager of the CSL. 'Such a book as we propose,' Eayrs told Enderby, 'would, I think, do a good deal towards bucking up holiday travel in the section of the country in which you are particularly interested.' 43

Enderby was impressed with the idea and suggested that Barbeau write a book along the lines of similar tourist-oriented publications in use in Great Britain. ${ }^{44}$ Barbeau had no difficulties with this suggestion. He agreed to tailor the book to the needs of the CSL, to make a research excursion to Charlevoix County to gather information, to use 'old people' in the employ of the company as sources 
for the book, and suggested that some of the folklore he had already collected could be modified to suit the routes of CSL cruises. 'You may note,' he told Enderby,

that the legends are localized in various places down the SaintLawrence. If you were interested in the book from the point of view of publicity, I may localize most of the legends at various points of ... Charlevoix and Chicoutimi [Counties]. The stories lend themselves to arbitrary localization. For instance in the Witch-canoe story, I could make the lumberjacks start from a camp on the Saguenay and travel along the coast in Charlevoix. That would at the same time give an idea of the location around there. 45

In addition to the modification of legends, other changes were also required to increase the level of local colour in the book. The one difficulty Enderby had with Eayrs and Barbeau's proposal was the book's title, In the Heart of the Laurentians, which was, he felt, more suggestive of skiing than a boat cruise. ${ }^{46}$ Barbeau agreed to change his title and asked Enderby if he had any suggestions for a new name. Enderby did not, and Barbeau experimented with In Search of Quebec before eventually suggesting The Kingdom of Saguenay which, he explained, was 'how Cartier and the other early mariners called this territory.' 47

To ensure that readers fully understood the significance of the title, Barbeau wrote an introductory chapter retelling the legends of the mythical Kingdom of Saguenay and recounting the adventures of early French explorers in their quest for it. ${ }^{48} \mathrm{He}$ also made a short expedition to Murray Bay to gather more local colour for the book and included a chapter called 'Tossing a Coin for a Seigneury' which recounted a supposedly significant event in local history. 'It is,' Barbeau explained to Eayrs, 'a vigorous contrast of the two seigneuries of Murray Bay . . . This ch[a]p[ter] may prove quite good and interesting to many readers. ${ }^{49}$ Periodically Barbeau sent drafts of the book and its art work to Enderby. He also stopped at Enderby's office in Montreal to maintain his interest, to ensure that he was happy with the text, and to encourage potentially higher levels of support. 'Perhaps,' Barbeau added in one letter to Eayrs, 'the two [draft chapters] and the summaries may interest Mr. Enderby into a special edition. ${ }^{\prime 50}$

The requirements for Quebec: Where Ancient France Lingers were even more specific. The idea for the book originated with the Librairie Garneau, a French-Canadian book-seller and publishing 
house interested in the tourist market. It was suggested to Barbeau in the fall of 1935 by Garneau's owner who was also interested in co-publication with Macmillan (whether or not this was at Barbeau's suggestion or request remains unclear). He agreed to purchase an advance order of 2,000 copies if Macmillan would handle the printing. Garneau had a very specific type of book in mind: it would be written in English and modeled after a Paris guidebook by Pierre Gauthier; it would be about 224 pages long with 25,000 words of text and over IOO, mainly photographic, illustrations; the retail price had to come in at $\$ 2.50$ per copy with the wholesale price at no more than $\$ 1.25$; it would have to be published before the up-coming tourist season - around the first of June I936; and Garneau would retain the exclusive right to sell the book in the province of Quebec. ${ }^{5 \mathrm{I}}$

Barbeau agreed to write the English text and look after the illustrations as he was also doing for The Kingdom of Saguenay. The Kingdom of Saguenay was illustrated with original art work, and Barbeau had recruited some of the leading painters in Canada as illustrators, including A.Y. Jackson, Arthur Lismer, André Bieler, and Yvonne Housser..$^{2}$ The CsL sponsored the paintings used in The Kingdom of Saguenay and paid each of the artists Barbeau had recruited for their work. In return, the CSL not only received original illustrations by noted Canadian artists for its tourist promotion literature, but also retained possession of the original paintings which were to be framed and displayed at the Manoir Richelieu hotel. 53

Eayrs had been cautious about the use of original art in The Kingdom of Saguenay. As it was, the cost of the illustrations exceeded the amount that the CSL had originally been prepared to spend, and although Enderby did not seem to object seriously to minor cost over-runs, there were limits beyond which he did not wish to go. ${ }^{54}$ Eayrs found it necessary to try to curtail some of the artistic elaborations that Barbeau wanted to incorporate into the book. For example, chapter head designs by Marjorie Borden were, Eayrs felt, too expensive for the resources with which he had to work. 'I am,' he told Barbeau, 'frankly, afraid of the extra expense on the Saguenay book along the lines of Miss Borden's proposed chapter heads. We know exactly what we have to go and come on and if, in addition to the drawings she is doing, the chapter heads are done also, it loads the book with just that much more expense.' 'Also', he added almost as a post script,' I shouldn't think that Enderby would buy those chapter head drawings as readily as the 
[wood] cuts and other drawings for which he is to be sponsor.'55

The use of photographs to illustrate Quebec required another approach. With The Kingdom of Saguenay, Barbeau had accorded considerable liberty to the artists he recruited to illustrate the book, and it appears, in fact, that the final selection of illustrations was left to A.Y. Jackson. ${ }^{56}$ With Quebec Barbeau selected the photographic illustrations himself, drawing primarily on publicity photographs in the Canadian Pacific and Canadian National Railways files. 'As the book is intended chiefly for Quebec publicity,' Barbeau wrote to Gibbon, 'you may be interested in its quality and may be able to let me chose a certain number of your best photographs or drawings of Quebec. . . .'57 Barbeau was also able to arrange for the CPR and the CNR to make minor financial contributions to both Quebec and The Kingdom of Saguenay to help cover the costs of reproducing illustrations..$^{58}$

The Kingdom of Saguenay and Quebec came together quickly during the late fall of I935 and the winter and early spring of I936. Barbeau worked rapidly writing chapters, selecting photographs for Quebec, and helping to co-ordinate the work of artists. Eayrs was overjoyed with what he considered the engaging and cheerful tone that The Kingdom of Saguenay was taking and told Barbeau so: 'I am delighted with the first chapter of THE KINGDOM OF SAGUENAY which I have read and re-read. I think the tone is most happy. The reader will be engaged from the first page on. ${ }^{59}$ The Librairie Garneau was similarly impressed with the mock-ups of Quebec. 'C'est un plaisir pour les yeux et pour l'esprit,' E. Desrochers of the Librairie told Barbeau. 'C'est merveilleux. Le succès est assuré,' he enthused. ${ }^{60}$ For his part Barbeau was happier with Quebec than with The Kingdom of Saguenay, but he felt that Macmillan had done an outstanding job with the production of both books. As Barbeau explained to G.E. Rogers at Macmillan: '[t]hey are beautiful books and I admired them greatly. You have done a beautiful piece of work as a publisher. Everybody seems to have great admiration for them.'6r

In their final forms The Kingdom of Saguenay and Quebec were markedly different in both style, format, and the way in which they presented the folk culture of French Canada. The Kingdom of Saguenay was a melange of legends, adventure stories, historical sketches, and stories of folk life, which were desigined to create a sense of the atmosphere of folk life along the lower St. Lawrence coast. Its artistic illustrations were not intended to draw readers' attention to specific geographic settings or textual descriptions of 
local culture, geography and history, but rather to contribute to the 'atmosphere' of the book. ${ }^{62}$ Quebec, by contrast, focused on a specific theme. It detailed the cultural life of Quebec City and its environs. In this book Barbeau depicted Quebec City as a 'quaint oasis' of distinct and almost fairy-tale like character in 'the midst of [the] man-made uniformity' that was modern North America. Almost everything about the city, he wrote, looked as though it were an eighteenth-century French town, and Barbeau carefully described the narrow, European-styled streets of the Old Town. An atmosphere of history, in Barbeau's description, hung in the air, and the ghosts of valiant heroes like Generals Wolfe and Montcalm still seemed present. The people of Quebec themselves were marked by their leisurely, carnavelesque spirit. 'You hear,' Barbeau noted in one passage, 'peals of laughter; children ride horseback on old battery guns and play amid small pyramids of cannonballs; or they may engage in round dances while singing "Sur le pont d'Avignon" or "Il était une vielle grand-mère digue dindaine." "A holiday spirit pervades the place,' he summarized. Quebec was a city possessed of a 'romantic atmosphere' which made it and its inhabitants appear more like art than reality, 'like that intangible, somewhat unreal, air of stage and grand opera. ${ }^{163}$

It proved easier to market Quebec than The Kingdom of Saguenay. Despite the support of the CSL, CPR and CNR, Eayrs seems to have been concerned about the volume's sales potential even before it was published. On 3 February 1936, as Barbeau was busy writing and revising material and ensuring that the illustrations were ready for both books, Eayrs wrote to ask if the Librairie Garneau would be willing to place a large order for The Kingdom of Saguenay. He was prepared, he told Barbeau, to let Garneau have the exclusive right to sales for all of Quebec if the order was large enough. Eayrs suggested 2,000 copies, but intimated that because the level of CSL sponsorship limited potential financial liabilities, he 'might be disposed to think of the Librairie Garneau having the Quebec market for I,O00 ...' 'You, rather than I,' Eayrs concluded, 'are the man to make such a proposal ...' and he left the matter to Barbeau's judgement. ${ }^{64}$

Barbeau did indeed interest himself in the marketing of The Kingdom of Saguenay. Like other authors at the time, he wrote the text for publicity fliers, recommended review copies be sent to specific people who he was sure would give the book a favourable press, ${ }^{65}$ and on Eayrs' suggestion also wrote the Librairie Garneau to see if they might be interested in a bulk order. ${ }^{66}$ In at least 
one instance Barbeau took the marketing initiative. He wrote the Quebec Tourist Bureau to see if they were interested in a large order of the book. The Quebec Tourist Bureau had itself recently begun to publish guidebooks to the province, Barbeau noted in a letter to the Bureau; perhaps, he suggested, The Kingdom of Saguenay would also fit into their plans: '[c]e livre est fait surtout pour intéresser l'étranger et les touristes dans le comté de Charlevoix, Ile-auxCoudres, et le Saguenay,' he explained. If the Bureau were willing to purchase 2,000 copies, Barbeau promised that he could get Macmillan to provide a good rate for the sale. ${ }^{67}$ The immediate results were not favourable, but Barbeau remained undaunted. He believed that The Kingdom of Saguenay's long-term prospects were positive even if sales were slow in the short term. As he explained to Eayrs: 'the Saguenay book is not considered as quite so much in demand in Quebec as the other [i.e., Quebec]. However, a book of this kind is a good investment (de bon fonds) and will remain so as long as there are tourists there.' 'Besides,' he added almost as an aside,' it might arouse interest in Quebec itself. ${ }^{\prime 68}$

With the publication of The Kingdom of Saguenay and Quebec, Barbeau's writing had clearly crossed the boundary between the scientific publications he edited for the Journal of American FolkLore and the popular market in which he had become increasingly interested. In the process, the folk culture he sought to portray was at times subtly, or perhaps not so subtly, reshaped by the publishing process, the demands of the books' sponsors, and the requirements of the market. These books were not simply attempts to reach a broad audience and to re-popularize traditional culture in the modern age. They were, in fact, not designed for the popular market the general reader whom Barbeau and Sapir had targeted as one of the markets for Folk Songs of French Canada - but a very specific market: the foreign, primarily American, tourist trade. The Kingdom of Saguenay and Quebec were designed to help sell FrenchCanadian folk culture as a modern leisure commodity. Through these books (and, we should note, a diverse array of other media), folk culture was being transformed into a vacation experience to be purchased for the relatively brief duration of a lower St. Lawrence cruise or a holiday in Quebec City, or to be commemorated for a lifetime in the pages of one of Barbeau's books. Barbeau was an active element in this process. He worked with Enderby, Garneau, and Macmillan to ensure that the texts met their requirements and at times took the initiative. He sought out prospective sponsorship money from the CSL, CPR and CNR, and marketed these books to 
these companies in a way which they would find appealing and which would suit their needs. The original idea for The Kingdom of Saguenay did not, after all, come from Enderby, but from Barbeau and Eayrs. Barbeau also took the initiative in trying to find sales opportunities for this book, contacting prospective sellers, such as the Quebec Tourist Bureau, before he had informed Eayrs about it.

Barbeau also seems to have enjoyed writing tourist promotion books. As Quebec and The Kingdom of Saguenay were coming together he had already begun to formulate plans for other tourist books which would, he hoped, also be published under the sponsorship of tourist industries. If The Kingdom of Saguenay and Quebec were successful, he told Eayrs in the spring of I936, he would undertake two other similar books: one on the Gaspé Peninsula and one on the Northwest Coast. 'They would,' he explained,' be heavily and beautifully illustrated, like the two just appearing. Gaspé should appeal to Quebec. I would have the illustrations subsidized by the CNR and the Quebec gov't roads and Tourist dept. ${ }^{169}$ A book on the Gaspé appealed to Barbeau not only because of the possible sponsorship it might receive from the government, but also because he believed it had a large potential market. Barbeau consulted with the Quebec Department of Roads, the government department responsible for tourism, in June 1936 and received what he considered to be a favourable response. One official with whom he spoke informed him, as he explained to Eayrs, 'that Gaspe is the best field for tourist sale of books [and] that it was possible for his department to contribute toward the cost of illustrations.' Barbeau also contacted the CNR publicity department and, while he could not get a definite commitment, he assured Eayrs that their 'attitude' made him believe that they too would help finance the proposed book. He promised to expand his knowledge of the Gaspé that summer during fieldwork in that region which he was conducting for the National Museum. ${ }^{70}$

The Northwest Coast book would be published under similar auspices. It would, Barbeau told Eayrs, 'presumably appeal to the two railways and B.C. ${ }^{71} \mathrm{He}$ had already secured a promise from Murray Gibbon at the CPR to donate $\$ 250.00$ to the project and had spoken to the CNR but had not as yet received a commitment. ${ }^{72}$ Because of his extensive anthropological fieldwork on the Northwest Coast, Barbeau felt competent to produce such a book and in fact suggested that the final product would be a modified form of a scientific ethnography, called Totemland, he had tried to interest 
Macmillan in publishing in I934. 'This book,' he had told Eayrs, 'is of some importance for its contribution to science. It brings out new facts about how America was first peopled. ${ }^{73}$ Macmillan does not seem to have ever been really interested in Totemland, largely, Eayrs told Barbeau, because there was no market for this type of material in Canada. ${ }^{74}$ Barbeau had tried to modify the form of the book to make it more marketable, such as including 'a number of Indian songs, which are very interesting melodies and are likely to attract ... musicians and conservatoires, ${ }^{175}$ and he also suggested that Macmillan investigate the possibility of marketing the book internationally as a means to broaden its potential sales, ${ }^{76}$ but exactly what modifications he felt were necessary to transform his scientific ethnography into a book that would appeal to the tourist market are not known because the idea never seems to have moved beyond the planning stages. Neither of the books was published and Barbeau does not seem to have written extensive drafts for either. Interest in Totemland does not seem to have been as great as Barbeau imagined it would be, and a bureaucratic re-organization of the Quebec Department of Roads delayed support for Gaspé until the Autumn of I936, after which the Quebec government seems to have lost interest in the project. ${ }^{77}$

The Kingdom of Saguenay and Quebec did not become mainstays of the Macmillan or Garneau catalogues. The books sold steadily, if not at a brisk rate, but were not reprinted once the stock was exhausted. They were, however, for their time, innovative books which illustrated the increasing importance of traditional culture in Quebec tourist promotion. ${ }^{78}$ In the late I930s and after the Second World War a number of other authors began to target the same type of market with the same type of material and Barbeau's name began to figure in Quebec travel literature as different travel writers cited his work. ${ }^{79}$ Barbeau also maintained his connection with this type of publishing. In 1956 he published a pictorial study of Quebec through Macmillan called I Have Seen Quebec which also targeted the tourist market ${ }^{80}$ and as late as 1963 he was still interested in the tourist market. He tried to arrange for Garneau to reprint I Have Seen Quebec and considered a request from the company to write another book along similar lines. 'I hesitate . . considering my other commitments,' Barbeau told F.A. Upjohn at Macmillan, '[b]ut if I decline the Librairie might seek satisfaction elsewhere as the demands of the tourist trade in years soon to come are pressing. ${ }^{8 \mathrm{I}}$ This time, however, Barbeau's other commitments, and failing health, prevented him from completing the proposed book. ${ }^{82}$ 
What of the Romancero? It was jointly published by Macmillan and Beauchemin in 1937, one year after Quebec and The Kingdom of Saguenay, and sold at a list price of $\$ 2.75$. Of all the Quebec houses he had investigated, Barbeau finally decided it best to work with Beauchemin, despite his views of the 'slovenly quality' of their work, because Macmillan handled the printing and, he explained to Eayrs, because they had 'the advantage of a large and established clientele. ${ }^{183}$ In its final form, the Romancero conformed to Barbeau's original intentions which made it markedly different from either Quebec or The Kingdom of Saguenay. The Macmillan advertising circular for the Romancero illustrated the differences. The advertisement for the collection spoke of the colourful nature of folk culture, but also of its rapid fading before the modern age. The folk culture of the Romancero was not a folk culture which could still be experienced by the summer traveller, but a culture which was meeting an abrupt and untimely end before the onrush of the modern age. This advertisement further explained that the collection was intended for the 'general reader' and that its selections were 'unsurpassed' in their aesthetic quality. They offered, in other words, the cultural experience of art as opposed to the experience of a vacation. 'Now that the [work of folk-song] collection is sufficiently complete,' the advertising flier read,

the work of publication has begun in earnest. These songs must be presented to the public for the benefit of general readers interested in a splendid oral literature ... and in folk melodies that are unsurpassed for rhythm, character and beauty; these melodies are the best possible material for musical inspiration. They are now to be the possession of the whole of Canada at large.

Instead of inviting readers to participate in a vacation-like atmosphere, the Romancero circular concluded by charging a prospective audience with a moral responsibility: 'It is planned to make this series of Romanceros almost yearly,' the circular stated, 'until most of the best songs have been published. Now it is the readers turn to play their part and enable the publishers to continue the series. ${ }^{184}$

Barbeau continued to believe in the importance and potential of the project. As with Quebec and The Kingdom of Saguenay, he recommended reviewers and helped with marketing. ${ }^{85} \mathrm{He}$ personally had addressed and mailed 300 circulars to prospective customers. 'I am anxious to help,' Barbeau explained to George Rogers at Macmillan, 'in the dispersal of this book.' 'You may let 
me have 300 copies [of the circular],' he suggested, 'which I would have addressed from my office to prospective buyers. And we will see the results. If it proves worthwhile, I [will] ask you for some more copying. ... ${ }^{86}$ The Romancero, like Barbeau's previous work, earned positive reviews. It did not, however, earn enough money to permit the continuation of Barbeau's planned series. Barbeau must have understood this because he did not try to interest Macmillan in any subsequent volumes in the Romancero series. His correspondence with the company shifted to different matters, including his other proposals for tourist books, a novel he had written about life on the Northwest Coast fur-trading frontier, several prospective ethnographic texts, and a song-book for the Girl Guides of Canada.

Publishing history in Canada is still, in many ways, in its infancy. ${ }^{87}$ The intertwining stories of The Kingdom of Saguenay, Quebec, and the Romancero suggest how more detailed studies of text-making processes can contribute to a broader understanding of Canadian cultural, as well as publishing, history. At the least, research in publishers' archives offers new ways of reading texts. It could also shed some light on the hazy area of authorial intention and contribute to an understanding of the development of Canada's culture industries. In the case of Barbeau's I93os folklore writing, a detailed study of the publishing process demonstrates something else as well: the complexly mediated process which brought part of his bibliography into being. For The Kingdom of Saguenay and Quebec, the publishing process became something more than a neutral medium through which the words and thoughts of an author were conveyed to a reading public. In both instances, publishers helped to generated the ideas for these texts and helped to shape the final product. This process produced more than superficial changes to the original folklore publishing plan Barbeau had brought to Macmillan in I93I. The failure of the Romancero to become the extended series he had hoped no doubt disappointed Barbeau and nearly thirty years later he tried to revive the project working through the National Museum's anthropological publication series. But, if Barbeau did not realize the publishing goal he set for the Romancero, he did, nonetheless, write a series of folklore books. That this series was something other than he had planned speaks both to his commitment to see folklore in print and the wider dynamics of Canadian culture in the r 930 . 
RÉSUMÉ

L'anthropologue et folkloriste canadien Marius Barbeau est probablement surtout connu aujourd'hui pour son impressionnante liste de publications qui inclue plus de Iooo notices et qui comprend un roman, des catalogues raisonnés et des histoires de l'art ainsi que des textes sur l'anthropologie et le folklore. De tous les sujets qu'a traités Barbeau, ses travaux sur le folklore furent pour lui les plus importants et en même temps les plus difficiles à publier. Il croyait que ses textes les plus importants sur le folklore, une série qui sera connue sous le nom de Romancero du Canada, aiderait à la renaissance de la musique folklorique mais son éditeur, Macmillan du Canada, était convaincu qu'il n'existait qu'un marché très faible pour ce genre de publication et refusa d'imprimer le premier tome sans une certaine forme d'aide financière. De I93 I à 1936, Barbeau s'employa à obtenir cette aide, découvrant par ce fait d'autres moyens de publier le folklore qui eux réussirent à mettre ses travaux sur le marché de lecteurs. Cette étude examine comment les efforts de Barbeau pour développer la publication du folklore dans les années '30 influença la présentation des oeuvres publiées de la culture traditionnelle canadienne-française. Ce travail est présenté comme un cas-type en histoire de l'édition et en histoire culturelle canadienne.

\section{NOTES}

An earlier version of this paper was presented to the 1996 Bibliographic Society of Canada annual meeting in Halifax. I would like to thank the conference participants, Mark O'Donohue, Leslie Howsam, Ian McKay, Carl Spadoni, and this journal's anonymous reviewers for their comments on an earlier version of this essay. I would also like to acknowledge the financial support of a Social Sciences and Humanities Research Council of Canada doctoral fellowship which enabled me to conduct the research presented in this essay and the archival staff of the Canadian Museum of Civilization for both permission to use the material from the Barbeau fonds and their kind assistance with my research.

I R.W. Brock to Marius Barbeau, 27 December I9Io, Marius Barbeau fonds, Canadian Museum of Civilization (hereafter Barbeau fonds), B-Mc-3527. The origins of the anthropology division of the Geological Survey of Canada are charted in Morris Zaslow, Reading the Rocks: The Story of the Geological Survey of Canada (Toronto: University of Toronto Press, 1975), 264-76.

2 Standard bibliographic guides to Barbeau's writings include: Clarisse Cardin, 'Bio-bibliographie de Marius Barbeau' Les Archives de Folklore 2 (1947): 17-96 
and Mario Béland, 'Marius Barbeau et l'art au Québec: bibliograhpie analitique et thématique' Outils de recherche du Celat I (1985).

3 Barbeau to Hugh Eayrs, I3 May I935, file 2, box 72 Macmillan fonds, William Ready Division of Archives and Research Collections, McMaster University. All further references to archival documents are to the Macmillan fonds unless indicated otherwise.

4 The limited market for Canadian folklore did affect Barbeau's scientific publications but not in the same way as he would later be affected when he tried to publish the Romancero. It was, for example, necessary to do some minor fund raising to ensure that the Canadian branches of the American Folk-Lore Society had the funds to support the costs of publishing Canadian numbers of the Journal of American Folk-Lore.

5 Biographical information drawn from Laurence Nowry, Marius Barbeau: Man of Mana (Toronto: NC Press, 1995).

6 For an outline of Sapir's program for the anthropology division see Sapir, 'The Work of the Anthropology Division of the Dominion Government,' Queen's Quarterly 20, I (I9I2): 60-9. See also Regna Darnell, Edward Sapir: Linguist, Anthropologist, Humanist (Berkeley: University of California Press, I990), 49-5I and 74.

7 Later Barbeau intimated that French-Canadian culture dominated the Lorette reserve. See for example Barbeau, 'Our Indians - Their Disappearance,' Queen's Quarterly 28,4 (autumn I93 I): 699. I have, however, been able to document only one instance during Barbeau's original Lorette fieldwork where a Lorette Huron presented aspects of French-Canadian culture as traditional Huron culture. See Barbeau to Sapir, I3 May I9II, Sapir fonds, Canadian Museum of Civilization (hereafter Sapir fonds), file I9, box 425 . There is, of course, no reason why aspects of one culture cannot be adapted to another culture without diluting or in some other way damaging the culture which adapts these elements. For a discussion see: James Clifford, The Predicament of Culture: Twentieth-Century Ethnography, Literature, and Art (Cambridge MA: Harvard University Press, I988), I-I7.

8 At the least we can say that the matter did not again figure in Barbeau's correspondence until I9I4. 'Curiosity' cited in Barbeau to Sapir, I3 May I9I I, Sapir fonds, file 19 , box 425 .

9 'Marius Barbeau Interviewed by L. Nowry at the National Museum of Canada, I965' Typescript transcribed by R. Landry (1982), 20. A transcript of this interview is on file at the Canadian Museum of Civilization.

Io Barbeau to Sapir, 25 August I9I4, Sapir fonds, file 2I, box 425.

I I Barbeau to Sapir, 2 October I9 I8, Sapir fonds, file 22, box 425.

I2 Barbeau, Jongleur Songs of Old Quebec (Toronto and New Brunswick, NJ: Ryerson and Rutgers University Press, I962), xxi.

I3 Boas to Barbeau, 2 September I9 I 8, Barbeau fonds, B-Mc-2726. Boas emphasized the 'scientific' nature of the planned French-Canadian numbers frequently in his correspondence with Barbeau. On I2 November 1915, for example, he chided Barbeau for suggesting that English translations accompany the French texts. Boas wrote: 'I do not think it will be necessary to accompany the French tales 
with English extracts; in fact it would seem to me to detract from the scientific dignity of the Journal if we should suppose our readers not able to read French.' Boas to Barbeau, I2 November I91 5, Barbeau fonds, B-Mc-2626. See also Boas to Barbeau, I4 March I917, Barbeau fonds, B-Mc-2679.

I4 Barbeau to Jean Beck, 3 I mars I9I7 (copy), Barbeau fonds, B-Mc-I700.

I5 Nowry, Marius Barbeau, 268 and 276.

I6 The fate of one early effort to use traditional culture as a tourist draw in Quebec City is detailed in Frank Abbott, 'Cold Cash and Ice Palaces: The Quebec Winter Carnival of I 894' Canadian Historical Review 69,2 (I988): 167-202.

I7 See C.H. Carpenter, Many Voices: A Study of Folklore Activities in Canada and Their Place in Canadian Culture (Ottawa: National Museums of Canada, 1979), 205-15 and 216-7 for a survey of folklore publications in Quebec from the mid-nineteenth century to the 1920 .

I 8 Barbeau to Sapir, 2 October I9I 8, Sapir fonds, file 22, box 425.

I9 'Introduction' to Barbeau and Sapir, Folk Songs of French Canada (New Haven: Yale University Press, I925), xiii.

20 Barbeau, Québec, où survit l'ancienne France (Québec: Librairie Garneau, 1937), I69.

2 I 'Preface' to Barbeau and Sapir, Folk Songs of French Canada, xi; Barbeau to Sapir, 24 August 1924, Sapir fonds, file 23, box 425 . Folk Songs of French Canada was published with a grant from the Oliver Baty Cunningham Foundation which had been established by Frank Cunningham in memory of Oliver who had been killed during World War I. The history of Folk Songs of French Canada would also make an interesting study in the impact the publishing process can have on the presentation of cultural material. Barbeau related this story to his future biographer, Laurence Nowry, in 1965 . See 'Marius Barbeau Interviewed by L. Nowry', 43.

22 Barbeau and Sapir, 'Preface,' xi.

23 For example see Ernest MacMillan, 'Folk Songs of French Canada,' Canadian Forum 6, no. 63 (December 1925): 79-82.

24 Barbeau to Sapir, 24 August 1924, Sapir fonds, file 24, box 425.

25 Barbeau contributed material to several smaller song books in collaboration in the late I920s. See Barbeau, Harold Bolton and Arthur Somervell, Twelve Ancient French-Canadian Folk-Songs (1927) and Barbeau, Paul England and Healey Willan, Chansons canadiennes (French Canadian Folk-Songs) (1929). The first of these titles is a thirty-nine page booklet published by Boosey \& Co. The songs in this book were drawn from material Barbeau collected. Bolton supplied the English translations and Somervell the musical arrangements. The second title is a two-volume collection consisting of twenty-seven and thirtynine pages for volumes one and two respectively. The songs published in this set were, like the first title, drawn from material Barbeau collected. Paul England translated the songs and Willan supplied the musical arrangements. It was published by The Frederick Harris Co.

In addition, songs from Barbeau's collection were published in other texts. For example, eleven songs from the Barbeau collection were published in Achille 
Fortier, Alfred Laliberté, Oscar O'Brien, Leo Smith et Ernest MacMillan, Vingtet-une chansons canadiennes avec traductions en anglais par J. Murray Gibbon (1928). This title was also published by The Frederick Harris Company. A number songs were also published in annotated programs for various folk-song concerts and in various newspapers. For a detailed bibliographic description of the different newspapers through which Barbeau published folk songs and legends see Cardin,' Bio-bibliographie de Marius Barbeau', 50-85.

26 Barbeau to Eayrs, 2I July I93 I (copy), Barbeau fonds, Hugh Eayrs file, temporary box 5 .

27 Barbeau to Albert Pelletier, I I janvier I935 (copy); Barbeau to Parmaley Day, 30 April I935 (copy). Both in file 6, box 72 .

28 For example see Eayrs to Barbeau, 2I August I923; John D. Robbins to Eayrs, 28 May 1927 (copy). Both in Barbeau fonds, Hugh Eayrs file, temporary box 5.

29 As Young notes, Eayrs used surpluses derived from Macmillan's profitable school text trade to subsidize the publication of unprofitable Canadian novels. See: David Young, 'The Macmillan Company of Canada in the r93os,' Journal of Canadian Studies 30,3 (1995): I17-33.

30 Eayrs to Barbeau, I3 December 1934 (copy) and 27 April I935 (copy); Eayrs to the Hon. L.A. Taschereau, 29 August 1932 (copy); Barbeau to Vincent Massey, 4 February 1935 (copy). All in file 6, box 72 .

3 I Eayrs to Taschereau, 29 August 1932 (copy); Barbeau to Eayrs, I 2 February 1935. Both in file 6, box 72 .

32 Eayrs to Barbeau, I I May I935 (copy), file 7, box 72.

33 Barbeau to Eayrs, 30 January I935, file 6, box 72.

34 Vincent Massey to Barbeau, 9 February 1935, Barbeau fonds, Vincent Massey file, temporary box 34 .

35 Barbeau to Albert Pelletier, I I janvier 1935 (copy), file 6, box 72.

36 Barbeau to Eayrs, 6 February I935; Pelletier to Eayrs, 5 February 1935. Both in file 6 , box 72 .

37 Eayrs to Barbeau, 26 April 1935 (copy), file, 6, box 72.

38 Barbeau to Eayrs, I2 and I3 February I935, file 6, box 72.

39 Barbeau to Pelletier, II janvier 1935 (copy), file 6, box 72.

40 Barbeau to Eayrs, 6 February I935, file 6, box 72.

4I Barbeau to Eayrs, 4 February I932 (copy), Barbeau fonds, Hugh Eayrs file, temporary box 5 .

42 Barbeau to E. Desrochers, 5 février 1936 (copy), file 4, box 72.

43 Eayrs to T.R. Enderby, I 3 February I932 (copy), Barbeau fonds, Hugh Eayrs file, temporary box 5 .

44 T.R. Enderby to Barbeau, 23 March I932, Barbeau fonds, T.R. Enderby file, temporary box 6 .

45 Barbeau to Enderby, I6 March 1932 (copy), Barbeau fonds, T.R. Enderby file, temporary box 6.

46 Enderby to Eayrs, 9 December 1935; Eayrs to Barbeau, I 4 November 1935 (copy). Both in file I2, box $7 \mathrm{I}$.

47 Quote from Barbeau to Enderby, I7 December 1935 (copy), Macmillan fonds, file 
I2, box 7 I. See also Barbeau to Enderby, 4 December I935 (copy), file 4, box 72 (suggesting The Kingdom of Saguenay) and Barbeau to Eayrs, I3 May I935, file 2, box 72 (on name In Search of Quebec).

48 Barbeau to Enderby, 17 December 1935 (copy), file I2, box 7I; Barbeau to Eayrs, 22 December 1935, file 4, box 72.

49 Barbeau to Eayrs, 7 January 1936, file 7, box 72. Barbeau discusses his excursion to Charlevoix county in Barbeau to Eayrs, 29 October I935, file 4, box 72.

50 Barbeau to Eayrs, 2 January 1936, file 7, box 72. See also Barbeau to Eayrs, 7 January 1936 , file 4 , box 72 .

5 I Barbeau to M. Garneau, I4 novembre I935 (copy), file I2, box 71; Barbeau to Eayrs, 29 October 1935 , file 4, box 72.

52 [Eayrs?] to George Pepper, 8 June 1936 (copy), file I2, box 71 , discusses payment arrangements for the different artists who illustrated The Kingdom of Saguenay.

53 Barbeau to W.H. Coverdale, 24 August I940 (copy), file I2, box 7I, discusses the arrangements made for the paintings.

54 Enderby to Eayrs, 9 December 1935, file I2, box 7 I.

55 Eayrs to Barbeau, 3 I December 1935 (copy), file I2, box 7 I. As it turned out, Eayrs was wrong on this count. Barbeau did manage to interest Enderby in the addition of Borden's chapter head illustrations. See Enderby to Barbeau, I 8 December I935 (copy), file I2, box $7 \mathrm{I}$.

56 G.E. Rogers to A.Y. Jackson, 30 January I 936 (copy), file I2, box $7 \mathrm{I}$.

57 Barbeau to J. Murray Gibbon, I3 November I 935 (copy), file I2, box 71; Gibbon to Barbeau, I 5 November 1935 (copy), file 4, box 72.

58 Eayr to Barbeau, 25 November 1935 (copy). The total level of sponsorship money amounted to $\$$ I 50.00 . The CSL was the largest sponsor donating a final total of $\$ 825.00$, most of which went to pay illustrators; the CPR was next at $\$ 250.00$, while the CNR offered the relatively modest contribution of $\$ 75.00$. Barbeau to Eayrs, 28 May 1936. Both in file 4, box 72.

59 Eayrs to Barbeau, 25 January 1936 (copy), file I2, box 7 I.

60 E. Desrochers to Barbeau, I 6 mai 1936 (copy), file 4, box 72.

6I [Barbeau] to G.E. Rogers, I3 August I 936 (copy), file 5, box 72.

62 This was one of the reasons Barbeau wanted to add Borden's chapter head designs to the book. As he explained to T.R. Enderby: 'The chapter heads would illustrate some feature within the following chapter, whereas the regular illustrations will illustrate the background only, being prepared without reference to my text.' Barbeau to Enderby, 17 December 1935 (copy), file I2, box 7 I.

63 Marius Barbeau, Quebec: Where Ancient France Lingers (Toronto: Macmillan of Canada, 1936), passim, but citations at I and 3 .

64 Eayrs to Barbeau, 3 February I936 (copy), file I2, box 71 .

65 Barbeau to Eayrs, 29 June I936, file 8, box 72; Barbeau to Rogers, 7 January I936, file 4 , box 72 .

66 Barbeau to Desrochers, 5 février 1936 (copy), file 4, box 72.

67 Barbeau to Le Directeur, Bureau du tourisme provincial, 23 mars I936 (copy), file 4 , box 72 .

68 Barbeau to Eayrs, Io February 1936, file 4, box 72. 
69 Barbeau to Eayrs, I8 May 1936, file 4, box 72.

70 Barbeau to Eayrs, 29 June 1936, file 8, box 72.

7 I Barbeau to Eayrs, I8 May 1936, file 4, box 72.

72 Barbeau to Eayrs, 29 June I936, file 8, box 72.

73 Barbeau to Eayrs, I5 September 1934, file 8, box 72.

74 Eayrs to Barbeau, 3 I January I 924 (copy), file 8, box 72 .

75 Barbeau to Eayrs, 7 March 1935 , file 8, box 72.

76 Eayrs to Barbeau, 24 September 1934 (copy), file 8, box 72 .

77 Barbeau to Eayrs, 2I October 1936, file 5, box 72.

78 See for example Abbott, 'Cold Cash and Ice Palaces,' passim.

79 Cf. Amy Oakley, Kaleidoscopic Quebec (New York and London: D. AppletonCentury 1947), 103-4 and 149; Blodwen Davies, Gaspé: Land of History and Romance (Toronto: Ambassador Books, I949), 33-4; and Henry Beston, The St. Lawrence (New York and Toronto: Farrar \& Rinhart, I942), x-xi.

80 I Have Seen Quebec was, in a number of ways, a very different type of book than Quebec or The Kingdom of Saguenay in that it was composed entirely of pictures with a minimal text intended only to identify the pictures. The pictures were designed to tell the story of Quebec in an aesthetically pleasing fashion. Publicity flier for I Have Seen Quebec in file 8, box $7 \mathrm{r}$.

8I Barbeau to F.A. Upjohn, 20 August I 963 (copy), Fonds Marius Barbeau, Archives nationales du Québec (Montréal), micro reel 5089 \#M699.9.

82 On Barbeau's declining health see Nowry, Marius Barbeau, Iо.

83 Barbeau to Eayrs, I3 February 1935, file 6, box 72.

84 Publicity flier: 'Romancero du Canada by Marius Barbeau' in file 7, box 72.

85 Barbeau to [Ellen] Elliott, Io June 1937, file 7, box 72. I suspect Barbeau also wrote the publicity flier for the Romancero as it used some of the text Barbeau had previously used in the 'Introduction' to Folk Songs of French Canada. Cf. Barbeau and Sapir, 'Introduction,' xiii.

86 Barbeau to Rogers, 5 January 1937 , file I2, box 7 I.

87 But see Janet B. Friskey, 'Beyond the Shadow of William Briggs, Part r: Setting the Stage and Introducing the Players' Papers of the Bibliographic Society of Canada 33,2 (I995): I 2 I-63; Ruth Panofsky, " "Don't let me do it!": Mazo de la Roche and Her Publishers' International Journal of Canadian Studies I I (I 995): I7 I-84; Sandra Campbell, 'From Romantic History to Communications Theory: Lorne Pierce as Publisher of C.W. Jeffreys and Harold Innis' Journal of Canadian Studies 30,3 (I995): 9I-II6; and Bruce Whitman, 'The Early Years of the Macmillan Company of Canada, I905-I92 I' Papers of the Bibliographic Society of Canada 23 (I984): 68-8I in addition to the essay by Young cited above. 